\title{
The Family Law Reform Act 1987 - Useful Reform but an Unhappy Compromise? \\ N. V. Lome*
}

\section{Introduction}

As it states in its long title, the object of the Family Law Reform Act 1987, is to reform the law relating to the consequences of birth outside marriage; to make further provision with respect to the rights and duties of parents and the determination of parentage, and for connected purposes. That such reform was needed could hardly be doubted since the pre- 1987 Act law relating to illegitimacy was both wrong in principle and inadequate in practice: the former, because it is surely indefensible for the law to discriminate against children simply because their parents were not married to one another; the latter principally because financial relief could only be obtained through the highly unsatisfactory means of affiliation proceedings. Moreover, with the growing number of children being born outside marriage (126,000 in 1985), ${ }^{1}$ the need for reform has assumed ever greater importance.

Insofar as the 1987 Act addresses these issues it is a most welcome piece of legislation. On the other hand, the Act is immensely complicated and at times obscure and even misleading; it does not abolish the concept of illegitimacy nor, indeed, are all the adverse consequences removed. It may therefore be questioned whether the Act goes far enough, and more generally whether its overall framework provides the best means for reforming the law. It is the intention of this article to examine these latter issues first and then to discuss the more important of the substantive provisions. ${ }^{2}$

\section{The basic strategy}

(i) Sections 1 and 2

As has been said, the 1987 Act does not abolish the concept of illegitimacy as such but instead adopts the strategy of substantially reducing the need to refer to that status. This is sought to be achieved first, by removing most (though

*Reader in Law, University of Bristol.

1. Office of Population Censuses and Surveys: Population Trends (1986), Table 11.

2. At the time of writing a number of the provisions have been implemented, principally ss.1, 18-22, and 26-29. For a complete list see further at $n .51$. 
regrettably not all) of the remaining areas of legal discrimination against illegitimate children and, secondly, in cases where it is still necessary to distinguish between children born within marriage and those born without (principally in relation to the rights and duties of fathers), reference is made to the parents (rather than the children) and whether or not they are married to one another. This general approach is set out in ss. 1 and 2 of the Act.

Section 1(1) provides that references in the 1987 Act and any succeeding Act or statutory instrument to "mothers" or "fathers" or "parents" refers, unless the contrary intention appears, to all such persons regardless of whether they have or had been married to each other at any time. ${ }^{3}$ The clarity of this opening provision is immediately obscured by definitional provisions designed to distinguish (in simple terms) parents (primarily fathers) of legitimate from those of illegitimate children. To avoid using the words "legitimate" or "illegitimate", s.1(2) refers instead to a person whose parents were not married to each other at the time of the child's birth. However, it was recognised that this shorthand definition was insufficient by itself because a child can be legitimate even though his parents were not married to each other at the time of his birth. Accordingly, s.1(2) is made subject to s.1(3) so that references to "a person whose father and mother were not married to each other at the time of the child's birth"4 do not include (correspondingly, references to a person whose parents were married to each other at the time of his birth $d o$ include) cases where the child is (a) legitimate even though his parents' marriage is void, (b) legitimated by reason of his parents' subsequent marriage, (c) adopted and (d) "otherwise treated in law as legitimate".

Although ss.1(2) and (3) have the laudable aim of redirecting the discriminatory labels from the child to the parents (it is clearly the spirit of the Act to refer to a child as being of unmarried parents rather than as an illegitimate child), they nevertheless make not just for complex but positively misleading law. Perhaps the best example of this is Schedule 2 Part I of the Marriage Act 1949 (this sets out whose consent is required for a minor's marriage) which, as a result of the amendments of the 1987 Act, $^{6}$ is headed "WHERE PARENTS OF THE CHILD WERE MARRIED TO EACH OTHER AT THE TIME OF HIS BIRTH". The unsuspecting reader might think that that Part means what it says and is confined to parents married at the time of the child's birth but this is not so

3. This is a reversal of the previous virtual presumption at any rate with regard to the expression "parent" (less obviously with regard to the expression "father") that it did not include the father of an illegitimate child.

4. By s.1(4) a child's birth is to be taken to include the period beginning with insemination resulting in his birth or, where there was no such insemination, his conception, and ends with his birth.

5. This is intended to cover the case, for example, where the child is conceived through AID and born to a married woman and who therefore, by virtue of 5.27 (discussed, infra), is treated in law as being the child, the woman and her husband.

6. Sched. 2, para 11. Note also the converse heading in Part II, i.e. "WHERE PARENTS OF THE CHILD ARE NOT MARRIED TO EACH OTHER AT THE TIME OF HIS BIRTH", substituted by 5.9 of the 1987 Act. 
because, by the newly substituted s.78(1A) of the 1949 Act, ${ }^{7}$ that heading must be construed in accordance with s.l of the Family Law Reform Act 1987 and therefore includes parents who have married each other after the child's birth etc..

Under s.2, certain existing statutes have to be construed in accordance with s.1 of the 1987 Act. Among these Acts ${ }^{8}$ is the Child Care Act 1980 "except Part I and ss.13, 24, 64 and 65 "'. The none too obvious intention of this amendment was to make the provisions of the Child Care Act 1980, ss.12 A-F, under which notice of refusal or termination of access to certain children in care has to be served on the parents who then have a right to challenge that decision in the juvenile court, applicable to putative fathers. ${ }^{9}$ As these provisions fall under Part $1 A$ (i.e. not Part I) of the $1980 \mathrm{Act}$ the intention was to have them construed according to s.l of the 1987 Act. ${ }^{10}$ However, since by an oversight, the definition of "parent" under s.87(1) of the Child Care Act 1980 (which expressly excludes putative fathers) has been left unaltered, it seems even after this implementation of s.2, putative fathers will still not have the right to challenge access decisions. ${ }^{10}$

\section{(ii) The background to these provisions}

Given the complexity of ss.1 and 2, one might question the appropriateness of the whole underlying strategy. To appreciate why this approach was adopted it is necessary to consider the background to the legislation. The Act is based upon the recommendations of the Law Commission. Originally, the Commission favoured the radical plan that the status of illegitimacy should be abolished altogether. ${ }^{11}$ They argued that since the label was itself discriminatory, true equality demanded not simply the removal of the remaining areas of legal discrimination but the abolition of the very status. Indeed so strongly were they committed to this view, that they were prepared to countenance the necessary corollary of their recommendations that all fathers should be treated equally. The overwhelming response, however, was against giving all fathers automatic rights and accordingly, in their full report on Illegitimacy, ${ }^{12}$ the Law Commission did not advocate abolition of the status though they did recommend a change in terminology with the terms "marital" and "non marital" replacing so far as possible "legitimate" and "illegitimate".

7. Added by Sched. 2 para. 10 (b) of the 1987 Act.

8. The others are the National Assistance Act 1948 s.42(1), the Family Law Reform Act 1969 s.6, the Guardianship of Minors Act 1971, the Guardianship Act 1973 Part I, the Children Act 1975 Part II and the Social Security Act 1986 s.26(3).

9. Which they clearly did not prior to the 1987 Act; see, e.g., Re P (Minon: Access), P. v. P. (Gateshead $M B C$ intervening) (1988) The Times 19 February.

10. See, e.g., the comment at [1988] Fam. Law 151. Admittedly other results are more clear; for example, it is absolutely clear that s.I of the Guardianship of Minors Act 1971 (which states that the child's welfare is of the first and paramount consideration in custody disputes) applies even as between unmarried parents. It will also be clear that the prohibition against mothers and fathers applying for custodianship under s.33(4) Children Act 1975, applies to unmarried fathers as well.

11. See their Working Paper No. 74 on Illegitimacy published in 1979.

12. Law Com. No. 118 (1982), particularly at Part IV. 
Although the Government accepted these proposals in principle, in fact no immediate action was taken, and in the meantime the Scottish Law Commission examined and reported on the issue. ${ }^{13}$ They observed ${ }^{14}$ that "so long as marriage exists and children are born there will be children born out of marriage. In some cases of children born out of marriage the parents will marry each other after the birth: in others they will not. These are facts and, short of abolishing marriage there is nothing the law can do about them." Like the English Law Commission they did not recommend abolishing the status of illegitimacy, but unlike that body the Scots could see no merit in introducing the new terms "marital and "non marital". As they said ${ }^{15}$ that "was just another way of labelling children, and experience in other areas, such as mental illness, suggests that new labels can rapidly take on old connotations." They concluded that they did not wish to see "a discriminatory concept of 'non maritality' gradually replace a disciminatory concept of 'illegitimacy"'. However, like the English Law Commission, the Scots did recommend that the terms "legitimate" and "illegitimate" as applied to people, should wherever possible cease to be used in legislation. To achieve this, they recommended that, where distinctions based on marriage were necessary, future legislation should distinguish between fathers rather than children and where it was thought necessary to distinguish people on the basis of whether or not their parents were married to each other at any relevant time (which they hoped would be a "very rare exception") it should be done expressly in those terms. The Scottish Law Commission's proposals were enacted in the Law Reform (Parent and Child) (Scotland) Act 1986.

Following these developments, the English Law Commission reconsidered its proposals and in a second report, published in October 1986, ${ }^{16}$ advocated reform along the Scottish lines. These recommendations were the ones enacted by the Family Law Reform Act 1987.

\section{(iii) Can the Law Commission's final recommendations be justified?}

Although it is a major criticism of the 1987 Act that it does not remove all legal discrimination against illegitimate children, it is nevertheless submitted that the Law Commission was right in 1982 to drop its recommendation that the status be abolished altogether and that all fathers be thereby automatically vested with rights over their children. As has convincingly been argued, ${ }^{17}$ there would be immense practical problems in giving all fathers automatic rights, particularly with respect to adoption and child care law, and the consequential delays and

13. Scot. Law Com. No. 82 (1984).

14. Ibid., at para. 9.1 .

15. Ibid., at para. 9.2 .

16. Law Com. No. 157.

17. Mary Hayes, 43 M.L.R. 299 (1980) . 
difficulties that would inevitably ensue would hardly be for the child's benefit. ${ }^{18} \mathrm{It}$ has nevertheless been argued ${ }^{19}$ that the status could have been abolished without giving all fathers equal rights, it being pointed out that: "it is perfectly possible to allocate rights between parents according to their marital status while holding that all children have equal status." This seems a strong argument but once the Commission felt unable to remove all the consequences of illegitimacy it was clearly not open to them to adopt such an option. In fact, however, by adopting the compromise of redirecting the label towards the parents, the Commission have come close to accommodating this suggestion.

It is also submitted that the Law Commission were right in 1986 to abandon their earlier proposed introduction of the terms "marital" and "non marital" and to adopt instead the Scottish model. While no doubt the new expressions would have made the task of drafting the legislation easier, nevertheless the comments of the Scottish Law Commission about the dangers of simply introducing new discriminatory labels for old, seem convincing. Does this conclusion therefore mean that our law has inevitably to be as tortuous and obscure as ss. 1 and 2 of the 1987 Act make it? It is suggested not. The Scottish legislation is noticeably simpler and with suitable adaptation could have profitably been incorporated into the English legislation.

Section 2 of the Law Reform (Parent and Child) (Scotland) Act 1986 defines who has parental rights and provides in effect that the mother automatically has such rights regardless of whether she is or has been married to the child's father, whereas the father has such automatic rights only if he or she has been married to the child's mother. Had this been done in substitution of ss.1(2)-(4) and had it been stated that a father without automatic rights would be known as the "putative father", then not only would many of the drafting difficulties have been solved, ${ }^{21}$ with the labelling still directed at the parent rather than the child, but it would also have employed a term already in common use.

\section{The substantive changes under the 1987 Act}

Despite the above criticism of s.1, for the remainder of this article it is nevertheless proposed to follow the spirit of the 1987 Act so that where

18. These problems have in no way been diminished by the decision in Gillick v. West Norfolk and Wisbech Area Health Authority [1986] A.C. 112. Hence, in this writer's view, that decision does not affect the validity of the view that all fathers should not be vested with automatic rights; $c f$ Stephen Cretney's tentative suggestion, at [1987] Fam. Law 404, that it might.

19. John Eekelaar, "Second Thoughts on Illegitimacy Reform", [1985] Fam. Law 261.

20. Section 2(2) makes it clear that the father has parental rights where the marriage is voidable or void, provided it was believed by him in good faith at the time of marriage to be valid.

21. Section $4(1)$, for example, (discussed, infra) would have simply stated: "The court may, on the application of the putative father, order that he shall have all the parental rights and duties with respect to the child." Admittedly, this approach would not provide a substitute for the headings in Sched. 2, Part II of the Marriage Act 1949 (adverted to, supra), though it is suggested that if the headings respectively referred to "A child whose parents are or have been married to each other" and "A child whose parents are not and never have been married to each other", that would at least be an improvement upon the 1987 Act's amendments. 
differentiation of status needs to be made it will be done by reference to the marital status of the parents rather than by labelling the children. As a matter of shorthand convenience parents of a child who are not and who have never been married to each other (excluding void marriage), will be referred to as "unmarried".

\section{(i) The further removal of legal discrimination against children of unmarried parents}

Many of the adverse legal consequences of being born of unmarried parents had already been removed prior to the 1987 Act. An important Act in that respect was the Family Law Reform Act 1969, s.14 of which provided that children born of unmarried parents have succession rights to their parents' estates and vice versa. However, the 1969 Act did not give such children any succession rights upon the intestacy of their grandparents or any collateral relatives, nor did it affect the devolution of an entailed estate nor entitle such children to take as an "heir". It is these omissions that have been addressed by the 1987 Act.

By s.18, the estate of any person, dying intestate after the provision comes into force, is to be distributed without regard to whether the parents of any claimant have or had been married to each other. As a result, children of unmarried parents will be able to claim on the death of, for example, a grandparent, brother or uncle. Similarly, he could claim on the death of a first cousin related through brothers whose parents were not married to each other. Because of the difficulty in tracing some fathers, whose identity might not be known, a person whose parents were not married to each other is presumed not to have been survived by his father or by anyone related to him only through his father, unless the contrary is shown. ${ }^{22} \mathrm{On}$ the other hand, it should be noted that the exoneration formerly given by 5.17 of the 1969 Act to trustees and personal representatives who fail to ascertain whether there are children of unmarried parents who can take on an intestacy and who distribute the estate without notice of their existence, is removed by s. 20 of the 1987 Act. This change had been recommended by the Law Commission ${ }^{23}$ upon the basis that (a) it would be inconsistent with the basic policy of removing distinctions based upon the child's status and (b) it in fact imposes no significantly greater burden upon trustees and personal representatives, given their ability to protect themselves by advertising for claimants. Whether the Commission was over sanguine in their views can be debated.

Another important change is provided for by s.19, which states that in any disposition whether inter vivos, by will or codicil, made on or after the section comes into force, the use of the word "heir" is not to indicate an intention that a person whose parents have never been married to each other is not to take an interest. By this means it will abolish the rule that only children of married parents can succeed to an entailed interest.

22. Section 18 .

23. See their Second Report (Law Com. No. 158), paras 3.8-3.12. 
This new construction of the term "heir" will not mean, however, that children of unmarried parents will thereby be able to succeed to property which is limited to devolve along with a dignity or title of honour. This is made clear by s.19(4). On the other hand this does not mean that such children will never be able so to succeed since that will depend upon the terms of the letters patent issued under the Great Seal. At the moment they are in a form ${ }^{24}$ which limits succession to the "heirs ... of his body lawfully begotten", which is enough to show a contrary intention against devolvement to children whose parents are unmarried. However, if Her Majesty were minded in the future to use the form "to $\mathrm{X}$ and the heirs of his body" then any child could succeed under the terms of s.19(2).

Apart from this latter point, the only remaining area of legal discrimination against children whose parents are unmarried is in respect to British citizenship. Under s.50(9) British Nationality Act 1981, children whose parents are unmarried can only claim citizenship through their mother. Hence, they are not entitled to British citizenship even though their father is such a citizen. This rule is unaffected by the 1987 Act. Although the Law Commission could see no reason in principle why this rule should not be changed, they felt unable to make definitive reform proposals since it was a United Kingdom matter and therefore outside their terms of reference. ${ }^{25}$ It is surely a matter of profound regret that the Government felt unable to change the rule. As one commentator ${ }^{26}$ has pointed out, with the advent of DNA Fingerprinting ${ }^{27}$ by which it has become significantly easier to establish parentage, it is now particularly hard to justify the retention of the current discriminatory rule.

\section{(ii) The abolition of affliation proceedings and the introduction of a new action under the Guardianship of Minors Act 1971}

Although the foregoing reform is not insignificant, of more practical significance are the provisions dealing with the courts' powers to grant financial relief in respect of children whose parents are unmarried. Adopting the Law Commission's recommendations, the 1987 Act abolishes affiliation proceedings ${ }^{28}$ and replaces them with a new action under the Guardianship of Minors Act 1971. The 1987 Act also repeals the statutory embargoes on making financial orders against unmarried parents in wardship and custodianship proceedings. ${ }^{29}$

As a result of the new provisions under the Guardianship of Minors Act 1971, it will be open to either parent to apply for financial relief. ${ }^{30}$ This will mean that for

24. See the discussion by the Law Commission in Law Com. No. 118, at para. 8.26.

25. See Law Com. No. 118, at para. 11.9. The Scottish Law Commission came to a similar conclusion; see Scot. Law. Com. No. 82, paras 8.3-8.5.

26. Stephen Cretney, [1987] Fam. Lam 404.

27. See, e.g., Re 7. [1988] l F.L.R. 65. It might also be noted that s. 23 of the 1987 Act amends s.20 of the Family Law Reform Act 1969 specifically to allow the courts to order such tests.

28. Section 17.

29. See, respectively, Sched. 2 para. 20 and Sched. 2 para. 61 .

30. Applications for relief will not in themselves put the child's custody in issue. 
the first time an unmarried father will be able to apply for an order against the mother. More significantly, the mother will no longer have to be "single", which means that a woman still cohabiting with her husband can apply for an order against another man whom she alleges to be the father. Another change is the removal of the need for the mother's evidence to be corroborated. Of course this will not obviate the need to establish paternity nor does it mean that the courts will necessarily act on uncorroborated evidence. ${ }^{31}$

Another important change introduced by these provisions is the removal of the three year time bar on making an application. This will mean that unmarried fathers who were safe from liability under the old law will no longer have that immunity. The Law Commission was hesitant in recommending this change $\mathrm{e}^{32}$ but in the end felt that the benefit to the child outweighed the detriment to the father. Whether the change will lead to a flood of actions remains to be seen, but as the Law Commission pointed out, in assessing what order, if any, to make, the court is directed under s.12A of the 1971 Act to consider all the circumstances of the case including the financial obligations that the father has or is likely to have in the foreseeable future. The length of time before the action is brought is surely likely to be an important factor in itself. In any event many fathers will have since acquired other family commitments and thereby limited their available resources.

Two other crucial changes are introduced by the new action. First, applications can be made to the High Court, county court or magistrates' court. This means that the latter court will lose its exclusive jurisdiction to grant financial relief for children of unmarried parents. Secondly, the two higher courts will have wide powers at their disposal, viz. they will be able to grant secured or unsecured periodical payments, lump sums of any amount and require "either parent to transfer to the other parent for the benefit of the child, or to the child, such property as may be specified ..." and to order settlements.

Precisely what impact these two changes will have is hard to say, though at a stroke they make the action attractive to middle class applicants who at the moment seem to avoid bringing affiliation proceedings. The power to make secured periodical payments orders and unlimited lump sum orders should certainly be useful in cases where the father is better off. It may also be anticipated that higher orders will be sought in the higher courts, particularly where the parents have been living together for any significant period. What use will be made of the powers to make property transfers or settlements is perhaps even more a matter of conjecture. The Law Commission ${ }^{33}$ did not envisage the power being used at all frequently, relying on the practice of the Divorce Courts to lean against making such orders. ${ }^{34}$ Whether this view proves well founded remains to be seen.

31. See Law Com. No. 118, para. 6.22.

32. Ibid., at para. 6.55 .

33. Ibid., at para. 6.6 .

34. See Chamberlain v. Chamberlain [1974] 1 All E.R. 33, at p.38 per Scarman LJ and Draskovic v. Draskoric (1981) 11 Fam. Law 87. 
It can be pointed out that unlike divorce proceedings where the court can make orders in favour of the spouse, in these proceedings there will be no such power and hence there will be a stark choice as to whether to make an order for the child's benefit or no order at all. It is suggested that as well as claims against rich fathers, a transfer order is likely to be sought in cases where the parents have cohabited for any length of time. In this latter context it seems quite reasonable to expect, particularly as the child's welfare will be the first and paramount consideration in these proceedings, that the courts will accept the need to preserve the parties' home as a home for the children. Indeed the Law Commission said ${ }^{35}$ that few commentators thought it a valid objection that a transfer was tantamount to giving the unmarried mother a right to support for her own benefit. Even if the court is not prepared to make an outright transfer for the child's benefit, it might be disposed to make a limited transfer until the child has grown up. If this view is taken by the courts then it might be that the Law Commission seriously underestimated the use to which these powers may be put.

In addition to providing an action for unmarried parents, the newly amended Guardianship of Minors Act 1971 provides for an independent right of certain adult children to seek financial relief against their parents. ${ }^{36}$ Under the new s.11D ${ }^{37}$ an action may be brought by any child, regardless of whether his parents are married to each other, provided (a) he is over 18 and "is, will be or (if an order were made under this section) would be receiving instruction at an educational establishment or undergoing training for a trade, profession or vocation, whether or not he also is, will be or would be in gainful employment" or there are other exceptional circumstances justifying an order; (b) his parents are not living together in the same household; and (c) there was no periodical payments order in force in respect of him immediately before he was 16 . Application may be made in the High Court or county court. Upon such an application the court is empowered to make an order requiring either or both his parents to pay to the applicant such periodical payments or lump sum as it thinks fit. What use will be made of this action remains to be seen.

\section{(iii) The unmarried father's right to apply for a parental rights and duties order}

Faced with opposition to the idea that all fathers should have automatic rights, the Law Commission instead proposed that unmarried fathers should be allowed to apply for a parental rights and duties order. In this way it was sought to give some recognition to caring but unmarried fathers. ${ }^{38}$ This proposal has been enacted by s. 4 of the 1987 Act. The effect of such an order is to vest all the rights and duties in the applicant that he would have had, had he been the married father.

\section{Ibid., at para. 6.7.}

36. This provision enacts the Law Commission's recommendations; see Law Com. No. 118, paras. 6.29-6.33.

37. Added by s.14 of the 1987 Act.

38. See Law Com. No. 118, paras 7.26 et seq. 
According to s.4(2) these rights and duties are to be shared with the mother, or, if she is dead, with any guardian appointed under the Guardianship of Minors Act 1971. Read literally this would appear to mean that such rights and duties will not therefore be shared with testamentary guardians, since they will not be appointed under the 1971 Act, but it is difficult to believe that this was what was intended. The order will remain in force even where the father and mother continue to live together but it can subsequently be discharged upon the application of the father, mother and, if the mother is dead, any guardian appointed under the Guardianship of Minors Act 1971 . $^{39}$

Application for a parental rights and duties order may be made in the High Court, County Court or Magistrates' Court. ${ }^{40}$ In deciding whether to grant the order the court must treat the child's welfare as the first and paramount consideration. ${ }^{40}$ If an application is made whilst the father and mother are still living together and the mother does not object to it, then no doubt the court will grant the order. In contested cases, however, the court will obviously have to consider what relationship the father has or has had with the child. If there has been no contact at all then it will be difficult to justify an order being made. On the other hand, if there has been a close relationship, then the mere fact that the court would not grant him day to day control does not ipso facto mean that a parental rights and duties order will be refused.

Precisely what use will be made of this action is a matter for conjecture. The Law Commission very much hoped ${ }^{41}$ that applications would be made while the mother and father are living together, in other words in cases where there is no dispute between the parties. One suspects, however, that few such applications will be made since most people only think about their legal position when things have already gone wrong. The Law Commission envisaged ${ }^{42}$ the new order being sought in two other situations, namely, where the mother dies having appointed no guardian and where the parents have separated and the father seeks full parental rights rather than legal custody. A section 4 application has obvious use in the former situation but at first sight there seems little to be gained from a parental rights order that cannot be gained from a legal custody order. However, an unmarried father would be well advised to apply for both, ${ }^{43}$ since were he to fail to gain legal custody, he would have no parental rights even if he were granted access. On the other hand, as previously stated, the refusal of a custody order does not ipso facto mean that a parental rights and duties order will be refused.

39. Section 4(3). Again this provision seems to exclude testamentary guardians.

40. Section 4(4).

41. See Law Com. No. 157, para. 3.3.

42. Law Com. No. 118, para. 7.29.

43. Cf. Stevens and Legge, "Illegitimacy Obscured but not Obliterated": An Analysis of the Family Law Reform Act 1987 [1987] Fam. Lam 409,410 who comment "where there is conflict, s.4 may well be bypassed as the father may be advised to apply for legal custody to be vested in himself alone or with a shared responsibility with the mother under the 1971 Act." 
Not everyone agrees that s. 4 is a good idea ${ }^{44}$ but in this writer's view it is a good compromise. Indeed one wonders whether the ambit of the provision could be extended to others, for example, step-parents or grandparents. It might be noted that under the equivalent provision in Scotland ${ }^{44}$ it is open to anyone to apply for such an order.

\section{(iv) New status for AID children conceived by a married woman}

At common law it was clear that a child conceived as a result of artificial insemination of a woman with the semen of a man other than her husband was illegitimate. This was so even if her husband agreed to the insemination. Many, including the Law Commission, ${ }^{46}$ felt this to be wrong, and following the Commission's recommendations, s.27 alters this position. By that section, any child born in England and Wales after the implementation of s.27, as a result of artificial insemination of a married woman with the semen of a man other than her husband, will, unless it is proved that the husband did not consent to the insemination, be treated in law as the child of those parties ${ }^{47}$ and not of any other person. In other words an AID child born to a married couple is presumptively the child of both parties, that presumption being rebuttable upon showing that the husband did not consent to the artificial insemination of his wife.

Although as a matter of status for the child this does seems a desirable change in the law, nevertheless it is a powerful objection that it will encourage such spouses to conceal the true origins of the child. Indeed it could legalise such deception if it is interpreted as entitling such persons to register the child as their own. It will also be noted that $s .27$ is limited to children conceived by artificial conception and does not apply to other forms of artificially aided conception. However, the Government intends to so extend the provision. ${ }^{48}$

Another, perhaps unintended, result of $s .27$ is to make surrogacy agreements, which take the form of a married woman agreeing to be inseminated by the semen of the "commissioning father", ${ }^{49}$ even more difficult to operate. In such cases, unless he can show that he did not consent to the insemination, the husband and not the "commissioning father" will be treated as the child's legal father. Consequently, any agreement between the mother and the "commissioning father" will be void under s.1(2) Guardianship Act 1973. Furthermore any placement with the "commissioning father" with a view to adoption will rank as a private placement and therefore an offence under s.11 Adoption Act 1976.

44. See, e.g., the trenchant criticism of the proposal by Eekelaar, [1985] Fam. Lam 261.

45. Section 3 of the Law Reform (Parent and Child) (Scotland) Act 1986 and see the comments of the Scottish Law Commission, Scot. Law Com. No. 82, at p. 97.

46. Law Com. No. 118, para. 12.7 et seq..

47. But note the proviso re succession to any dignity or title of honour pursuant to s.27(3).

48. See their White Paper: Human Fertilisation and Embyology: A Framework for Legislation $(1987 \mathrm{Cm}$. 259), para. 89.

49. As in Re P. (Minors) (Wardship: Surrogacy) [1987] 2 F.L.R. 421. 


\section{(v) Other changes}

The 1987 Act contains a number of other important provisions to which brief attention must now be paid. First there are the provisions under Part $V$ dealing with registration of birth. As a result of these amendments the provisions of the Births and Deaths Registration Act 1953 have been extended ${ }^{50}$ inter alia to allow a man alone to request his name to be entered as the father, provided the application is accompanied by (a) a declaration stating himself to be the father and (b) a statutory declaration by the mother stating him to be the father.

There are also provisions dealing with the court's power to grant declarations of parentage. Section 22 amends s.56 Family Law Act 1986 inter alia to permit an unmarried person being declared a parent. The following declarations can now be sought: (1) that the person named in the application is the mother or father, or that particular persons are the parents of the applicant; (2) that the applicant is the legitimate child of his parents; and (3) that the applicant has or has not become legitimated.

Section 23 makes the useful and important amendment to s.20 Family Law Reform Act 1969, so as to permit the court to order "scientific tests" and thereby enable DNA fingerprint testing to be carried out.

\section{Conclusions}

The 1987 Act contains important and worthwhile reform. Unfortunately, that reform is marred by complexity and obscurity. Perhaps, given that the Law Commission's recommendations, upon which the Act is based, are in the nature of a compromise some of the complexity is inevitable. However, as it is hoped to have been demonstrated in this article not all of the Act's imperfections were unavoidable and indeed if the Scottish model had been more closely followed, our own law could have been a great deal simpler.

Despite its imperfections it must nevertheless be hoped that the whole of the Act is implemented as soon as possible. At the time of writing a number of provisions of the Act have already been implemented. ${ }^{51}$ At the moment, however, there are no plans to implement those provisions dealing with the abolition of affiliation proceedings and the creation of a new action under the Guardianship of Minors Act 1971. Given that in practical terms, those are the most important of the reforms of the 1987 Act it can only be hoped that the Government have an early change of mind.

50. Following the Law Commission's recommendations at Law Com. No. 118, paras. 10.63 et seq. 51. Viz ss.1, 18-22, 26-29, 31, 33 (part), 34; Sch 2, paras. 2-4, 9-11, 16 (c), 19, 59, 73, 74, 96; Sch 3, paras. 1, 8-10; Sch 4 (part); SI 1988/425. These provisions came into force on 4 April 1988. 